\title{
ANALYSIS OF COST OF MILK PRODUCTION IN RATNAPURA DISTRICT
}

\author{
T.S.P. Jayaweera ${ }^{1}$, H.A.D. Ruwandeepika ${ }^{1}$, K.M.S.B. Kendaragama ${ }^{1}$, \\ W.A.P. Fernando ${ }^{1}$, H.M.K.P. Jayarathne ${ }^{1}$ and T.S.J. Thotawaththe ${ }^{1}$
}

\begin{abstract}
The success of Dairy farming, as a form of business, depends on profitable milk production and marketing. The price of milk depends on various factors such as demand, supply, cost of production, location of the area and marketing channel. Profit margin in the dairy industry has been considered to rest on the difference between the cost of production per liter of milk and the average farm gate price for milk. The objective of this study was to identify the factors affecting the cost of milk production in Ratnapura District and suggest a reasonable and appropriate price for a liter of milk produced by dairy farmers in the district considering the cost of production of milk.
\end{abstract}

A field survey was conducted using a pre-tested questionnaire on the cost of milk production in the area. Two hundred and fifty dairy farmers were selected from the district for the study by using simple random sampling method.

The highest amount of cost has been spent for labour. It was estimated to be $44.1 \%$ of the total cost while $41.7 \%$ of the total cost represents the feeding cost. The rest of the cost is due to other operational costs, like cost of depreciation of initial investment $(3.1 \%)$, cost of veterinary services $(3.2 \%)$, cost of building repairs $(0.6 \%)$, cost of death and losses (4.9\%) and breeding \& miscellaneous costs $(2.4 \%)$. The costs of production of a liter of milk by an average farmer, when his family labour costs are included and excluded were Rs. 25.50 and Rs. 14.60 respectively. The average price paid to all farmers surveyed was Rs. 28.75 per liter of milk. It greatly varies with fat content of the milk. Average herd size of the area was four animals per farm. Average milking cows per farm were 2.8.It is recommended to have a minimum price of Rs.30 per liter of milk to make dairying a fairly profitable for farmers in the area.

Keywords: Dairy farming, Milk production, Cost

\section{INTRODUCTION}

Milk is the secretion of mammary glands of female mammals. Cow milk as an article of food for mankind antedates the earliest recorded history. A classification of the principle constituents of cow milk is as follows. Water $87.55 \%$, Dry matter $12.75 \%$, Fat $3.8 \%$, Protein $3.5 \%$, Sugar $4.8 \%$ and Ash $0.65 \%$ (Eckles et al., 2002).

Cow milk is a white opaque fluid with some exceptions where it is tiny yellowish in some breeds (Eckles et al., 2002). Because of its content of almost all essential nutrients, cow milk is being used throughout the world for feeding infants \& as a supplement to the diets of children $\&$ adults. In cow milk fat along with some fat soluble vitamins (Vitamin A,D,E \& $\mathrm{K}$ ) are present as an emulsion, Protein along with some mineral matters in colloidal suspensions, Lactose together with soluble minerals \& Vitamins are in true solutions(Eckles et al., 2002).

Dairy farming is a small segment in the national economy of Sri Lanka and it is

${ }^{1}$ Department of Livestock Production, Faculty of Agricultural Sciences, Sabaragamuwa University of 
predominantly in the hand of small scale farmers. Despite the increasing demand for milk, milk production in the country fulfills only about $15 \%$ of the domestic demand (Central Bank, 2005).

The dairy industry is very important and has tremendous potential in developing the economy in the country. Milk production has been a traditional industry that has survived thousands of years (Siriweera, 1982). It was not for commercial purposes but for the own consumption of the households to optimize their nutritional requirements. From the ancient time they had a habit of rearing at least one cattle in each house. For that they had used minimum number of resources which was acquired mostly from their households.

However, a drastically reduction of involvement in the sector at present can be observed due to various factors such as uncertainty, lack of reputation, severe land fragmentation, industrialization, attitudes, economic factors, political and several other factors (Livestock statistics, 2004). The contribution of the agriculture sector to the Gross Domestic Production (GDP) was $20.7 \%$ in $1999,17.9 \%$ in 2004 and the $17.2 \%$ in 2005 . The livestock sector contribution to the agricultural GDP also has reduced accordingly (Central Bank,2000 and 2005).

Total land area of Sri Lanka is around $65525 \mathrm{Km}^{2}$. As a tropical country Sri
Lankan weather fluctuation is very minimal. However there are 24 agro ecological zones, which have been categorized based on the average annual Rainfall, elevation and soil type. Therefore there are slight weather differences in these areas. According to the 2005 statistics there was about 1218000 of cattle population within the country, but has not evenly distributed throughout the country (Livestock census, 2005). The total cow milk production of the country is 161.8 millions liters (Central Bank, 2005).

It has identified seven cattle farming systems in the entire Island (Ratnayake, et al,.1992).Major cost factors for the dairy sector in Sri Lanka are feed cost, labor cost and, veterinary cost etc (Chamberlain,1993). Various factors that can influence the dairy farm's cost of production can be categorized in figure 01 .

Ratnapura is the Capital of the Sabaragamuwa province and it has a total land area of 3,27,562 hectares and the district belongs to low country wet zone with an average annual rainfall of $3000-4000 \mathrm{~mm}$, which is rather moderately distributed throughout the year and average annual temperature of $25^{0}-27^{0} \mathrm{C}$ while the elevation of the district is ranging between 259-3596 feet from the mean sea level. It has rather a higher RH \%. (Development plan, 2000). The climatic conditions in the district are much favorable for a successful Dairy rearing with higher performances. 


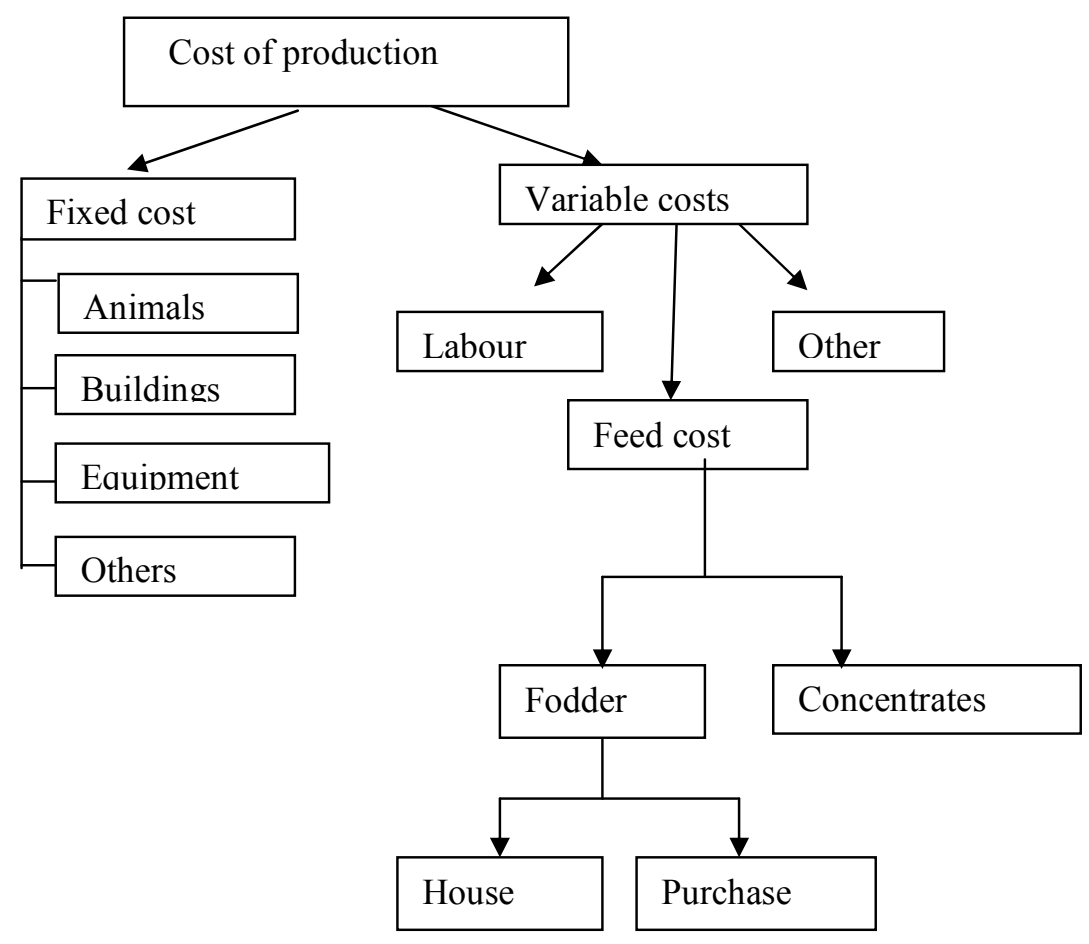

Figure 01: Factors that affect on the cost of production of a Dairy farm.

Livestock is a major sub sector of the Agriculture of the district and the dairy sector plays a major role at this juncture. However the country itself as well as the Ratnapura district faces the problem of moving back of farmers who involved in the dairy sector. This is mainly because of the lesser economic attractiveness of the Dairy industry when compared with other economic activities of the people in the area. The economy of the district is mainly based on the plantation sector and the gem industry, causing the migration of people from dairy sector to the aforementioned other sectors which would benefit them more. As a result of this the milk production in the District has been declining annually at a considerable rate. Most of the cattle farmers in Ratnapura were observed to be small scale (Livestock statistics
2004). The profit margin in the dairy industry has been considered to rest on the difference between the cost of milk production per liter of milk and the average farm gate price of milk (Payne, 2001).

The aim of this study was to identify the factors affecting the cost of milk production in Ratnapura District and suggest a reasonable and appropriate price for a liter of milk produced by dairy farmers in the district considering the cost of milk production.

The advantage of conducting this type of analysis is to evaluate the old plan of milk production and guide the farmer to adapt a new plan with advantages. It makes farmer careful of leakage or wastes in the operation of the farm. It gives a corporative study 
of receipts, expenses and net earnings on farm. It also guides and encourages the most efficient and economic use of available resources. It serves the base for future improvements in farm practices. It gives rooms to a milk producer to compare different segments of his total expenditure with another milk producer and may take judicious measures to curtail the expenditure on production of milk. Finally, milk producer can implement such principles of management which would help in reducing the cost of milk production.

\section{MATERIALS AND METHOD}

\section{Study area}

This study was carried out within 16 divisional secretary divisions of the Ratnapura district. The cattle population in the district was 16000 according to the 2005 data and most of the farmers in the area practice intensive and semi intensive cattle management systems (Livestock Statistics, 2004) and there are 5 state farms within the study area.

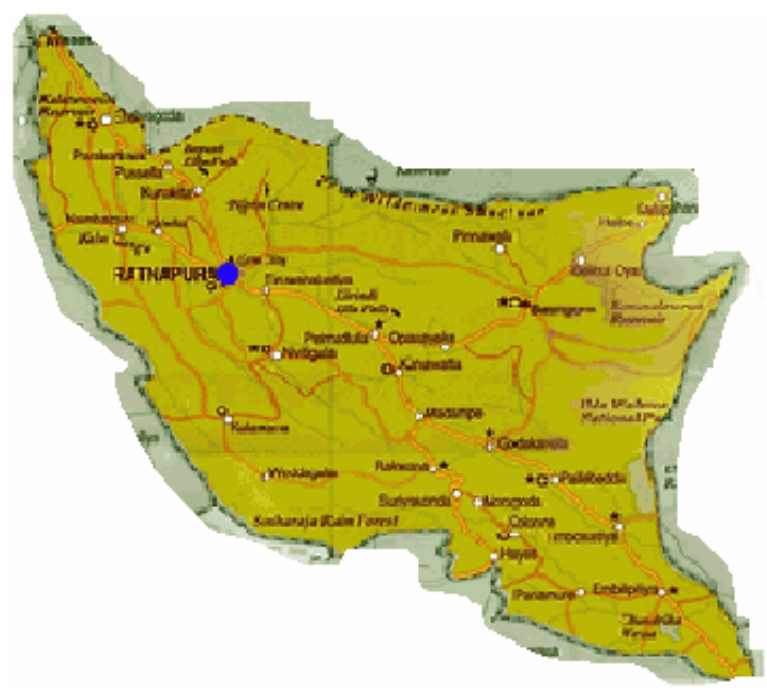

Figure 02: Ratnapura District: The study area

\section{Study Design}

The information needed for this study was collected using a well structured pre-tested questionnaire. The data were gathered by visiting individual dairy farmers and collected the information pertaining to cost of milk production from the records maintained at the dairy farms and also by interviewing the farmers. The data were regarding expenses on labour, feed, veterinary cost, maintenance cost and income etc.
The study covered two hundred and fifty Dairy farmers. Selection of farmers was done using the simple random sampling method. The study period was from December 2004 to January 2006.

\section{RESULTS AND DISCUSSION}

Cost factors considered in this study come under two categories, fixed cost and recurrent costs. Cost of Animals and buildings were categorized under 
fixed cost and the cost of equipment which is also a fixed cost was neglected as it was very low in quantity.

\section{Fixed costs}

\section{Herd expenses}

Most of animals in the selected farms were crossbred. A small number of local animals were available, but the existence of pure Breeds was naught. Popular cross breeds were Friesian, jersey, Ayreshire, Sahiwal, AMZ and AFS which have been selected according to the climatic conditions of the area. The average number of milking cows per farm was three.

The total cost spent for animals can be calculated as follows;

\section{Depreciation}

Purchase cost of Estimated value animals $\quad-$ of cow's life

Number of Years of productive life

It was assumed that the productive life of a cow is 7 years and after 7 years the established value is Rs. 4500.00 .

$$
\begin{aligned}
\text { Depreciation } & =\frac{(18800 * 3)-(4500 * 3)}{7} \\
& =\text { Rs. } 6128.57
\end{aligned}
$$

\section{Building}

Irrespective of the management system of the farms, the buildings had not been constructed up to the standards in many cases. In most of the cases the floor had been constructed using cement and the roof by cadjans or sheet. Cemented feeder and waters were prominent in most occasions.
Assuming that an individual animal require about 70 sq. feet floor area and the cost per square feet construction is Rs. 1900.74,

The total cost per cattle Shade $=70 * 3 * 120$

$$
=\text { Rs. } 399156.50
$$

Depreciation value was calculated as follows;

The total cost per cattle shade

$$
\text { Life of the cattle shade }
$$

(Assumption; the existence of cattle shade is 50 years)

Depreciation value $=$ Rs.399156.50/ 50

The depreciation per year=Rs.7983.13

Total Depreciation of heard

fixed $=$ Expenses + Depreciation of

cost building expenses

$$
\begin{aligned}
& =\text { Rs. } 6128.57+\text { Rs. } 7983.13 \\
& =\text { Rs. } 14111.70 / \text { year }
\end{aligned}
$$

\section{Variable costs}

Labor is the remarkable factor that governs the variable cost of production for a farmer (Prasad, 2001). On average there were two laborers per farm, which are normally hired and had been used for a wide range of activities in milk production process. Other than the hired labor, some farmers had used the family labor as well. In the study the opportunistic cost was also considered for family laborers assuming that they have a chance to engage in another occupation. It was assumed that each family laborer would have earned the wages similar to the hired laborer during the study period. 
Daily Payment per labor $=$ Rs. 275

Average number of

laborers in the farm $=2$

$$
\begin{aligned}
\text { Labor cot per year } & =275^{*} 2 * 365 \\
& =\text { Rs. } 200750.00
\end{aligned}
$$

\section{Feed cost}

Majority of the farmers of the study were practicing semi intensive and intensive management systems. The feed cost was apparently high under these management systems as the cut and fed method is practiced and in addition due to utilization of commercially prepared feeds. On average $3.5 \mathrm{Kg}$ of Coconut Poonac was given daily per animal as concentrate. In addition, Rice bran was also used as a concentrate.

Some farmers owned few hectares of grassland but some had to bring them from outside. The labor usage in the second method was much higher than that of the first method. The average daily roughage requirement was 130 Kg per farm.

Price of $1 \mathrm{Kg}$ of coconut Poonac is Rs. 22 and price of $1 \mathrm{Kg}$ of rice bran is Rs. 10 .

Average feed cost per day $=$ Rs. 520

Total feed cost per year $=520 * 365$

$$
=\text { Rs. } 189800
$$

\section{Veterinary cost}

The veterinary costs in the studied farms accounted a low worth as the farmers have not concerned much on veterinary facilities.

In many cases it had been a difficult task to find a veterinary surgeon in need. The Veterinary costs included the cost of drugs and the transport cost of the veterinary surgeons.

Average Veterinary cost

Per month = Rs. 1213.90

Veterinary cost per year $=$ Rs. $1213.9 * 12$

$=$ Rs. 14566.80

\section{Cost for building repairs}

The cost of building repairs was high in urban areas than villages as most of the village farmers had neglected it. The major cost for building repairs are floor maintenance, repairing leakages, wall maintenances and drainage maintenance etc.

Average cost of building repairs per day $=$ Rs. 227.60

Average cost of building repairs per year

$$
\begin{aligned}
& =277 * 12 \\
& =\text { Rs. } 2731.30
\end{aligned}
$$

\section{Cost of death and losses}

The major cost factor considered is the death of animals, calf mortality, theft and injuries.

Average cost per month $=$ Rs. 1858.80

Average cost per year $=1858.80 * 12$

$$
=\text { Rs. } 22305.60
$$

\section{Breeding and miscellaneous cost}

The minor cost factors which were not included in the aforementioned cost factors have been considered in this category. A considerable amount of cost had to be spent on breeding of the existing animals. Hiring of Breeding Bulls and the transport cost for the AI technicians were high. The other costs have been spent on infrastructure facilities such as water and electricity etc. 
The average Breeding-and miscellaneous cost - = Rs.910.43 -per month

The average reading and miscellaneous cost per year

$$
\begin{aligned}
& =910.43 * 12 \\
& =\text { Rs. } 10925.25
\end{aligned}
$$

Total variable cost $(\mathrm{TVC})=$ labor cost + feed cost + veterinary cost + building repair cost +death and losses + breeding and miscellaneous cost
Total fixed cost $=$ Depreciation for herd expenses + Depreciation for buildings

$$
\mathrm{TVC}=(200750+189824+14566.90
$$$$
+2731.30+22305.60+10925.20)
$$

TVC $=$ Rs. 441103.00

Total cost $=$ Fixed cost + Variable cost

$$
=(14111.70+441103.00)
$$$$
=\text { Rs. } 455214.70
$$

Table 01: Summary of the total cost

\begin{tabular}{lll}
\hline Fixed cost & Rs./year & $\%$ \\
\hline Depreciation for herd & 6128.57 & $1.4 \%$ \\
Depreciation for buildings & 7983.13 & $1.7 \%$ \\
Total fixed cost & 14111.70 & \\
Variable cost & & \\
Labor cost & 200750.00 & $44.1 \%$ \\
Feed cost & 189824.80 & $41.7 \%$ \\
Veterinary cost & 14566.90 & $3.2 \%$ \\
Building repairs & 2731.30 & $0.6 \%$ \\
Death and losses & 22305.60 & $4.9 \%$ \\
Breeding and miscellanies & 10925.20 & $2.4 \%$ \\
Total variable cost & 441103.00 & \\
Total cost & 455214.70 & $100 \%$ \\
\hline
\end{tabular}

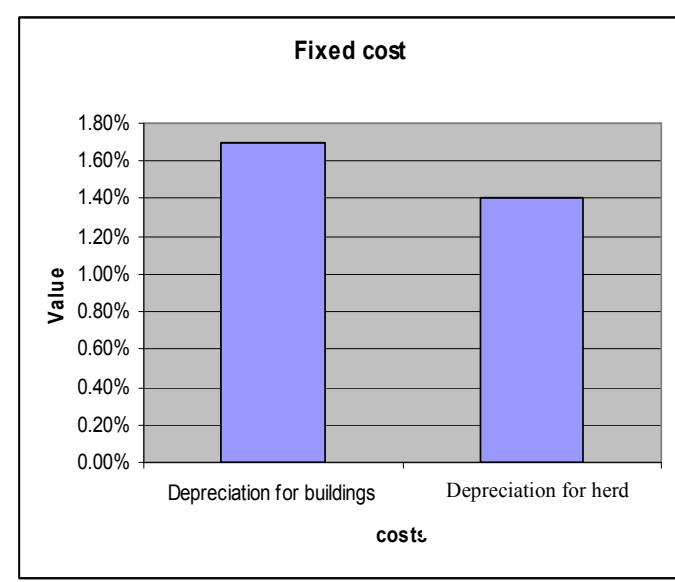

Figure 02: Analysis of Fixed cost

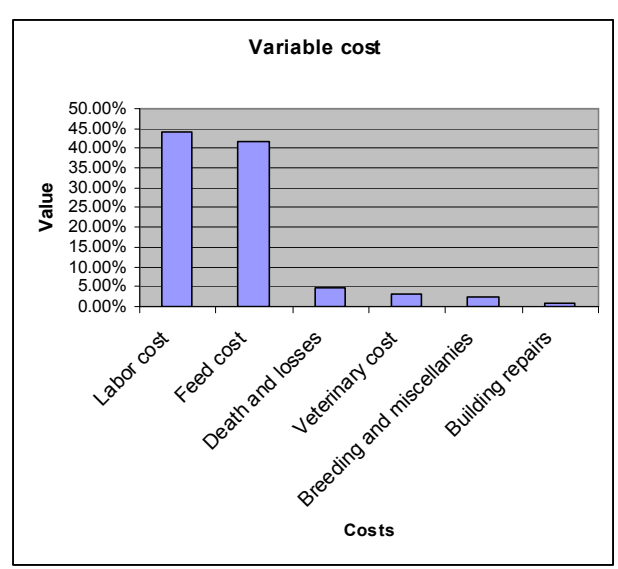

Figure 03: Analysis of Variable cost 


\section{Income}

The profit margin of the farmer solely depends upon the difference between the various costs factors and the income that is generated through various sources or out put of the farm (Prasad, 2002). In every farm the major portion is received through the selling of milk and other income sources are selling of manure, selling of male calves and adult animals when their performances are poor, The total cost of production has been calculated above and the price per liter of milk produced can be calculated as follows by subtracting the total cost from the income of the farm.

\section{From milk}

Average number of liters per day

$$
\begin{aligned}
& =13.7 * 2.8 \\
& =38.36 \mathrm{~L}
\end{aligned}
$$

(One animal gives 13.7 liter of milk per day)

The average length of the lactation period of a cow was 208 days.

Total milk yield per year $=38.36^{*} 208$

$$
=7978.88 \mathrm{~L}
$$

The average price per liter $=$ Rs. 28.75

Total income from milk per year

$$
\begin{aligned}
& =\text { Rs. } 28.75 * 7978.88 \\
& =\text { Rs. } 229392.80
\end{aligned}
$$

\section{From manure}

The average income by selling manure per year is Rs.2095.75

\section{From selling animals}

The average income by selling animals per year is Rs. 20200.00.
Total income per year $=($ Total income from milk + Total income from maneuver + total income from selling animals)

$=(229392.80+2095.75+20200.00)$

$=$ Rs. 251688.55

When the family labor cost is valued and included in the variable cost,

The average Total cost

total cost of per year

production $=$ Total number of

per liter of liter of milk

milk Per year

$$
=\frac{455214.70-251688.55}{7978.88}
$$$$
\text { = Rs. } 25.50
$$

When the family labor cost is not included in the calculation, the average cost of production per liter of milk is only Rs.14.60.

\section{CONCLUSIONS}

It is apparent that the uppermost portion of the cost of production of milk in Ratnapura district is owed for labor service. The profit for a liter of milk produced is only Rs.3.25 when the family labor cost is also incorporated in the calculation. As many industrial opportunities exist in the present trade market with much attractive income levels, this very low profit margin in the Dairy sector makes it a low attractive industry among people and cause departure of many farmers from the Dairy industry towards various other occupations.

When the family labor cost is not included as an opportunistic cost in the calculation, the profit per liter of milk 
raises up to Rs. 14.15, which lies at an appropriate level. Therefore it is always recommended to use family members who can not employ in any other business as labor suppliers to the Dairy industry.

To avert leaving of farmers from the Dairy industry, immediate actions have to be taken to improve the profit margin. An increased price per liter of milk at the farm gate will attract farmers back to the industry as it increases the profit margin. It is recommended to have a minimum price of Rs.30 per liter of milk to make dairying a fairly profitable industry for farmers in the area.

It is also possible to increase the profit margin by increasing the productivity of cows, by decreasing the price of animal feed stuffs and also by making available a better veterinary service for Dairy farmers with effortless access as well as at an affordable cost. The milk collecting system of the area needed to be strengthened through improvement of transportation and milk delivery to the collecting centers. The credit facilities for farmers need further revision. An integrated approach is beneficial in achieving these goals. Anyway the need to reduce costs and the means of doing so may vary with the farming system adopted by Cattle farmers. This requires a system approach and a strategy directed at the unique farming system. An eco specific development strategy could help identify and solve such limitations, for which a bottom to top approach could be more appropriate.

\section{References}

Central Bank of Sri Lanka.(2000).Annual Report. Colombo.

Central Bank of Sri Lanka.(2005).Annual Report. Colombo.

Chamberlain, A. (1993). Milk Production in the Tropics. Educational low priced book Scheme. Longman Scientific and Technical Publishers.UK.

Department of Animal Production and Health. (2004).Livestock statistics. Peradeniya.

Eckles, C.H., W.B. Combs and H. Macy (2002). Milk and Milk Products. $4^{\text {th }}$ edition.Tata McGraw-Hill Publishing Company Limited. New Delhi. pp 2122

http/www.statistics.gov.lk. (2005).Livestock Census.

Payne, W.J.A. (2001). An introduction to Animal husbandry in the tropics. $4^{\text {th }}$ edition. Educational low priced book scheme. Longman Scientific and Technical Publishers. UK.

Prasad J. (2001). Animal Husbandry and Dairy Science. $3^{\text {rd }}$ edition. Kalyani Publishers. New Delhi. pp 202-217

Prasad, J. (2002). Principles and Practices of Dairy Farm Management. $4^{\text {th }}$ edition. Kalyani Publishers. New delhi. pp 34-39

Provincial ministry of Agriculture, Sabaragamuwa Province.(2000).Development plan for Sabaragamuwa province.

Ratnayake, D., H. Abeygunawardena, M.W.A.P. Jayatilaka and W.D.Abayawansa (1992). Identification of distinctive Cattle farming systems in Sri Lanka and estimation of their production costs. Trop. Agric. Res., 4.

Siriweera, W.I. (1982).Water Resources and Cattle and Buffalo rearing in Sri Lanka; A historical perspective. ARTI publication, No.30, Colombo. 